УДК $378.015 .31-051: 111.852(043.3)$

Маріанна Мирошникова, здобувач кафедри педагогіки Хмельнииької гуманітарно-педагогічної академії, викладач кафедри загальноправових та сочіально-гуманітарних дисциплін Херсонського факультету Одеського державного університету внутрішніх справ

\title{
РОЛЬ ПРОФЕСІЙНОЇ ПІДГОТОВКИ У ФОРМУВАННІ ЕСТЕТИЧНОЇ КУЛЬТУРИ МАЙБУТНІХ ОФІЦЕРІВ НАЦІОНАЛЬНОЇ ПОЛІЦІЇ УКРАЇНИ
}

У статті висвітлюються актуальні питання формування естетичної культури майбутніх офіцерів національної поліції України. Йдеться про роль професійної підготовки у залученні курсантів вищих навчальних закладів МВС України до естетичних иінностей, розвитку у майбутніх правоохоронців естетичного ставлення до професійної діяльності, формуванні естетичної свідомості, вияву естетичної активності та естетичної поведінки. Автор аналізує зміст професійної підготовки та ї̈ вплив на естетичний розвиток майбутніх правоохоронців, висвітлює думки вчених щодо значення професійноі освіти у формуванні емоційно-естетичних, інтелектуально-естетичних та креативно-естетичних якостей співробітників органів внутрішніх справ.

Ключові слова: естетична культура, майбутні офічери начіональної полічїі, професійна підготовка, вищі навчальні заклади МВС України.

Puc. 2. Лim. 5.

\author{
Marianna Myroshnykova, Applicant of the Pedagogy Department \\ Khmelnytskiy Humanitarian Pedagogical Academy \\ Lecturer of the General Law and Social and Humanitarian Disciplines Department \\ Kherson Faculty of Odessa State University of Internal Affairs
}

\section{THE ROLE OF PROFESSIONAL TRAINING IN FORMATION OFAESTHETIC CULTURE OF FUTURE OFFICERS OFTHE NATIONAL POLICE OF UKRAINE}

The article covers the actual items of forming the aesthetic culture of future officers of the National Police of Ukraine. The article deals with the role of professional training in attracting cadets of higher educational establishments of the Ministry of Internal Affairs of Ukraine to aesthetic values, the development of future law enforcers the aesthetic attitude to professional activity, the formation of aesthetic consciousness, the manifestation of aesthetic activity and aesthetic behavior.

The author analyzes the content of professional training and its impact on the aesthetic development of future law enforcement officers. The article highlights the opinions of scientists on the importance of vocational education in the formation of emotionally aesthetic, intellectually aesthetic and creative - aesthetic qualities of the law enforcement officers, and the potential opportunities of professional training for the formation of aesthetic culture of officers of the National Police of Ukraine. It emphasizes the updating of the tasks of higher education in the field of aesthetic education, the introduction of methodological approaches and principles of formation of aesthetic consciousness. The article describes the enrichment of aesthetic experience of future specialists, by using the aesthetic-educational technologies, the development of the mechanism of selforganization of aesthetic culture as a personal spiritual-functional formation. As a result of the theoretical research, the author emphasizes that professional training is an important factor in the development of emotionally aesthetic, intellectually aesthetic and creative-aesthetic qualities of future law enforcement officers.

The main opportunities of the higher educational institutions of the Ministry of Internal Affairs of Ukraine, which promote the successful resolution of the problem of formation of the aesthetic culture of future officers of the National Police of Ukraine, are: actualization of the problem of formation of aesthetic culture among cadets; definition of methodological approaches to its solution; realization of the principles of formation of aesthetic culture, enrichment of the content of the aesthetic culture of future police officers; use of the effective pedagogical technologies; development of the mechanism of self-organization of aesthetic culture of cadets.

The article summarizes the results of scientific research and justifies the role of vocational training in forming the aesthetic culture of future officers of the National Police of Ukraine.

Keywords: aesthetic culture, the future officers of the National Police, professional training, higher educational establishments of the Ministry of Internal Affairs of Ukraine.

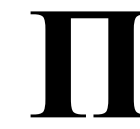

остановка проблеми. Вихід українського суспільства на новий етап цивілізаційного розвитку суттєво актуалізував проблему формування особистості, підготовки іï до життя в демократичному суспільстві, розвитку найважливіших духовних, психологічних, культурологічних та творчих якостей. Наголошуючи на важливості й необхідності оновлення існуючої освітньо-педагогічної 
практики В.О. Кремень зазначає, що “формування громадянського суспільства необхідно починати із створення оптимальних умов для соціального і особистісного розвитку всіх учасників педагогічного процесу. Немає сумнів в тому, що намагання глибше збагнути психологічні закономірності розвитку особистості, розкрити психологічні механізми цього процесу сприятиме побудові науково обгрунтованих технологій педагогічної діяльності у найширшому розумінні останньої, яка має бути підпорядкована реалізації найголовнішої мети - громадянському вихованню фізично і психічно здорової особистості, розвитку її національної свідомості та самосвідомості. Ця мета може бути успішно досягнута за умови об'єднання зусиль освітньовиховних закладів України з невичерпними можливостями всього нашого суспільства" $[1,17]$.

У формуванні особистості, розвитку їі естетичної культури особлива роль належить вищій школі, яка покликана створити необхідні умови, пов'язані з активним освоєнням світу прекрасного, набуттям естетичного досвіду, виявом творчої активності у професійній діяльності. Як зазначає Г. Шевченко, “в естетичній свідомості акумулюється естетичне як “безпосередня виразність" предметів, явищ навколишнього світу, що реалізується у багатогранних особистісних відношеннях до природи, праці, науки, мистецтва, людини. Ці відношення як власне людські співвідношення $\epsilon$ результатом різноманітної культурної діяльності людини, вони відображають гармонійність розвитку особистості, єдність абстрактнологічного та чуттєво-образного мислення. В основі естетичної свідомості лежить конкретнообразне мислення, яке з його характерними особливостями - інтуїцією, творчою уявою, передбаченнями - властиве не тільки художньоестетичній, а й науковій діяльності” [2, 219].

Для майбутніх офіцерів національної поліції України питання формування естетичної культури як складової професійної діяльності набуває важливого значення, розглядається як умова ефективності та якості виконання службових обов'язків. У зв'язку у цим у вищих навчальних закладах МВС України посилюється увага до морально-етичної та естетичної освіти й виховання курсантів, набуття ними необхідного досвіду естетичного ставлення до навколишньої дійсності, оволодіння способами самостійного сприймання, усвідомлення та використання на практиці моральних та естетичних цінностей.

Відповідно до Закону України "Про національну поліцію” 3 метою формування в поліцейських почуття відповідальності стосовно дотримання професійно-етичних норм поведінки під час виконання службових обов'язків, а також сприяння посиленню авторитету та довіри громадян до Національної поліції України Міністерством внутрішніх справ України затверджено Правила етичної поведінки поліцейських (Наказ № 1179 від 9.11. 2016 р.). Згідно цих Правил під час виконання службових обов'язків поліцейський повинен: неухильно дотримуватись положень Конституції та законів України, інших нормативно-правових актів, що регламентують діяльність поліції та Присяги поліцейського; професійно виконувати свої службові обов' язки, діяти лише на підставі закону, у межах повноважень; поважати і не порушувати права і свободи людини; виявляти повагу до гідності кожної людини, справедливо та неупереджено ставитись до кожного, незважаючи на расову чи національну приналежність, мову, стать, вік, віросповідання, політичні та інші переконання, майновий стан, соціальне походження, освіту та ін.; поводитись стримано, доброзичливо, відкрито, уважно і ввічливо, викликаючи в населення повагу до поліції і готовність співпрацювати; контролювати свою поведінку, почуття та емоції, не дозволяючи особистим симпатіям або антипатіям, неприязні, недоброму настрою або дружнім почуттям впливати на прийняття рішень та службову поведінку; мати охайний зовнішній вигляд, бути у встановленій формі одягу; дотримуватись норм ділового мовлення, не допускати використання ненормативної лексики та ін. [3].

Важливо зазначити, щоу формуванні естетичної культури майбутніх офіцерів національної поліції України особливу роль покликана відігравати професійна підготовка, яку проходять майбутні інспектори патрульної поліції, дільничні інспектори, інспектори - криміналісти, слідчі, співробітники карного розшуку в системі вищої освіти. У процесі навчальних занять, наукової роботи, позааудиторної та культуротворчої діяльності майбутні правоохоронці покликані ознайомитись 3 основними вимогами та критеріями естетичної культури, оволодіти уміннями і навичками встановлення плідного діалогу в умовах ділового спілкування, набути досвід естетичного сприймання, оцінювання та творчої інтерпретації естетичного змісту предметів та явищ навколишньої дійсності. Усвідомлення важливості успішного вирішення цих питань зумовлює необхідність теоретичного обгрунтування ролі професійної підготовки у формуванні естетичної культури майбутніх офіцерів національної поліції України. 


\section{РОЛЬ ПРОФЕСІЙНОЇ ПДГОТОВКИ У ФОРМУВАННІ ЕСТЕТИЧНОЇ КУЛЬТУРИ МАЙБУТНІХ ОФІЦЕРІВ НАЦІОНАЛЬНОӤ ПОЛІЦІЇ УКРАЇНИ}

\begin{abstract}
Аналіз останніх досліджень. Наукові розвідки вчених, присвячені питанням естетичної освіти й виховання майбутніх правоохоронців, дозволили виділити ряд важливих аспектів, що характеризують роль професійної підготовки у залученні курсантів вищих навчальних закладів до естетичних цінностей. Так, аналізуючи вищий заклад освіти МВС України, М. Ануфрієв, О. Бандурка, О. Ярмиш вказують на широкий спектр духовного впливу на майбутніх правоохоронців у процесі вивчення суспільно-гуманітарних дисциплін. А. Баранов зосереджує увагу на розкритті змісту та особливостей процесу естетичного виховання слухачів вищої школи системи МВС України засобами мистецтва. У дослідженні І. Ващенко висвітлюються питання формування пізнавальної самостійності курсантів вищих навчальних закладів МВС як основи їх професійної підготовки, у дисертаційній роботі В. Вергегел проаналізовано процес формування естетичних смаків курсантів вищих навчальних закладів МВС України.
\end{abstract}

Помітний інтерес викликають науковопедагогічні дослідження, в яких висвітлюються можливості професійної підготовки в моральноестетичному вихованні майбутніх правоохоронців. Так, праця I. Воробйової присвячена іміджу працівника правоохоронних органів та його формуванню у процесі професійної підготовки. У дослідженні І. Грязнова аналізуються зміст та особливості естетичного виховання майбутніх фахівців в умовах вищого навчального закладу. Результати наукового пошуку Т. Зубач дозволили висвітлити питання формування естетичних компетенцій у курсантів вищих навчальних закладів МВС України засобами іноземної мови. На необхідності морально-естетичного виховання засобами гуманітарних дисциплін курсантів вищих навчальних закладів МВС України наголошує Н. Карпунова, про розвиток професійно-моральних якостей майбутніх працівників правоохоронних органів у вищих навчальних закладах МВС України пише I. Марчук. У дисертації Н. Могілевської досліджено можливості формування естетичного відношення до людини укурсантів вищих навчальних закладів МВС України. Науково-педагогічне дослідження В. Серебряка дозволило актуалізувати питання духовно-морального виховання курсантів вищих навчальних закладів системи МВС України.

Отже, в сучасній науковій літературі отримали певне висвітлення питання естетико-виховного змісту та особливості їх вирішення у процесі професійної підготовки майбутніх працівників правоохоронних органів. Водночас залишається ще недостатньо обгрунтовано роль професійної підготовки у формуванні естетичної культури майбутніх офіцерів національної поліції України як системного й динамічного духовнофункціонального утворення особистості, здатного забезпечувати належний рівень естетичного освоєння дійсності та дотримання естетичних вимог у процесі професійної діяльності.

Мета статті полягає у теоретичному обгрунтуванні професійної підготовки як важливого чинника естетичного розвитку правоохоронців та розкритті потенційних можливостей професійної освіти у формуванні естетичної культури майбутніх офіцерів національної поліції України.

Виклад основного матеріалу. Важливо зазначити, що формування естетичної культури особистості відбувається під впливом багатьох чинників. Йдеться, зокрема, про вплив природного, предметного, сочіального та художнього середовища, в якому перебуває особистість. У науковій літературі вчені намагаються розкрити естетико-виховні можливості природи рідного краю, предметів побуту, системи етнокультурних родових та сімейних відносин, а також творів художньої літератури, музичного, театрального, хореографічного, образотворчого, декоративно-вжиткового та інших видів мистецтва.

Окрім навколишнього середовища естетиковиховний вплив на особистість здійснюють різні види діяльності, такі як, ігрова, комунікативна, навчальна, трудова, спортивна, творча та ін. На думку вчених (С. Мельничук, В. Бутенко, Г. Шевченко та ін.), залучення особистості до певних видів діяльності дозволяє зосереджувати увагу на естетичному освоєнні навколишньої дійсності і водночас виявляти естетичні якості, пов'язані зі сприйманням, оцінкою, осмисленням та інтерпретацією предметів, явищ, процесів тощо.

У процесі естетичного розвитку майбутніх правоохоронців важливого значення набуває професійна підготовка, яка здійснюється у вищих навчальних закладах МВС України. Як засвідчує досвід наукових спостережень, професійна підготовка курсантів вищих навчальних закладів охоплює широкий спектр питань, пов'язаних 3 формуванням у них естетичного ставлення до навколишньої дійсності, розвитку естетичної активності, набуттям досвіду естетичного сприймання професійних дій поліцейського, естетичною організацією ділових комунікацій тощо. Усе це дозволяє констатувати, що професійна підготовка являє собою важливий 


\section{РОЛЬ ПРОФЕСІЙНОЇ ПІДГОТОВКИ У ФОРМУВАННІ ЕСТЕТИЧНОЇ КУЛЬТУРИ МАЙБУТНІХ ОФІЦЕРІВ НАЦІОНАЛЬНОЇ ПОЛІЦІЇ УКРАЇНИ}

чинник естетичного розвитку майбутніх правоохоронців.

На основі теоретичного аналізу професійної підготовки як чинника естетичного розвитку майбутніх правоохоронців нами визначено декілька параметрів іiї естетико-педагогічного впливу, пов'язаних з розвитком емоційноестетичних, інтелектуально-естетичних та креативно-естетичних якостей (рис. 1).

Вплив професійної підготовки на розвиток емочійно-естетичних якостей майбутніх правоохоронців. Наголошуючи на важливому значенні професійної підготовки в естетичному розвитку майбутніх фахівців вчені (Т. Бабенко, М. Бабков, О. Бандурка, А. Баранов, І. Бех, А. Буров, Н. Бутенко, В. Вертегел, Л. Грицай, Л. Джигун, В. Долженко та ін.) зосереджують увагу на емоційно-естетичних якостях, необхідності та доцільності їх цілеспрямованого розвитку. Адже, емоційно-естетична активність особистості цінності, аналізувати і обирати їх для себе згідно з естетичними потребами” $[2,222]$.

В умовах професійної підготовки майбутніх правоохоронців важливо спрямувати освітньопедагогічні зусилля на розвиток таких емоційноестетичних якостей, як вміння естетично сприймати предмети і явища, виявляти інтерес до проявів естетичного в навколишній дійсності, відчувати емоційний характер та ціннісну забарвленість професійних дій, уміння співпереживати та емоційно реагувати на естетичні прояви в системі професійної діяльності, контролювати власні емоції та почуття, виявляти уважне ставлення до розвитку естетичних почуттів, смакових уподобань, ціннісних орієнтацій та ідеалів. У науковій літературі наголошується на ролі професійної підготовки у розвитку емоційно-естетичної активності курсантів вищих навчальних закладів МВС України.

Професійна підготовка як важливий чинник естетичного розвитку майбутніх правоохоронців

\begin{tabular}{l|} 
Вплив професійної \\
підготовки на розвиток \\
емоційно-естетичних \\
якостей майбутніх \\
правоохоронців
\end{tabular}

Рис. 1. Відображення професійної

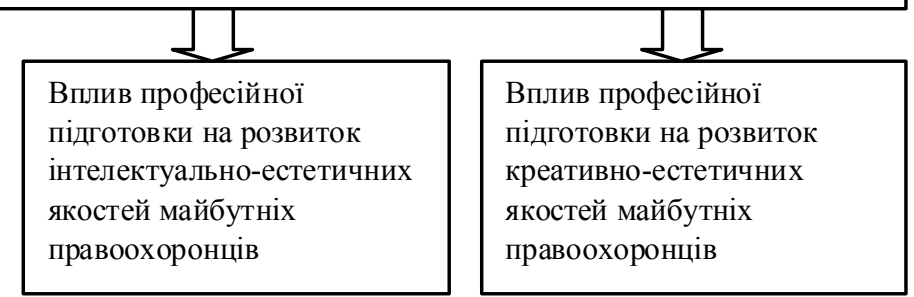
майбутніх правоохоронців створює важливі передумови для успішного вирішення професійних завдань, пов'язаних 3 організацією ділового спілкування, глибокого проникнення та сприймання окремих якостей та властивостей навколишнього середовища, генерування інноваційних ідей, прояву творчого ставлення тощо.

Водночас вчені висловлюють занепокоєння станом розвитку естетичних якостей майбутніх фахівців. Як зазначає Г. Шевченко, “в умовах дефіциту культури в сучасному суспільстві досить розмитими $\epsilon$ ціннісні орієнтації і естетична культура студентської молоді. Студентська молодь переживає нині серйозні труднощі, пов'язані 3 проблемами світоглядної культури, наявності потреб у духовних цінностях, працевлаштування, вибору естетичних ідеалів тощо. Студенти мало обізнані з національним мистецтвом, класичним мистецтвом, мають недостатньо вибіркове ставлення до естетичного. На наш погляд необхідно розвинути передусім у студентської молоді емоційно-почуттєву сферу, яка дасть можливість відгукуватися на справжні естетичні
Вплив професійної підготовки на розвиток інтелектуально- естетичних якостей майбутніх правоохорониів. Як зазначають вчені (І. Зязюн, Т. Іванова, Т. Ісаєнко, Н. Карпунова, О. Кайданова, К. Лесик, Г. Локарєва, І. Марчук, С. Мельничук, Н. Могілевська, М. Назарова, Ю. Пастухова, Г. Петрова, Л. Петько та ін.) у процесі професійної підготовки важливого значення набувають питання інтелектуально-естетичного розвитку майбутніх фахівців. Йдеться про такі інтелектуальноестетичні якості, як наявність необхідних знань в галузі естетики, розвиток естетичної компетентності фахівців певного профілю, формування системи естетичних понять та естетичного світогляду студентів, уміння самостійно аналізувати, порівнювати, співставляти, оцінювати та інтерпретувати естетичні прояви навколишньої дійсності, здатність до самоконтролю та самооцінки власних естетичних якостей, уміння моделювати професійні дії з урахуванням законів краси тощо.

Немає сумніву, що в умовах професійної підготовки особистість має можливість отримати 


\section{РОЛЬ ПРОФЕСІЙНОЇ ПІДГОТОВКИ У ФОРМУВАННІ ЕСТЕТИЧНОЇ КУЛЬТУРИ МАЙБУТНІХ ОФІЦЕРІВ НАЦІОНАЛЬНОӤ ПОЛІЦІЇ УКРАЇНИ}

необхідний інтелектуально-естетичний досвід. Як зазначає В. Бутенко “способи інтелектуальноестетичної активності відображають досвід освоєння мистецтва, в якому визначальне місце займає осмислення, аналіз, узагальнення. Основу інтелектуально-естетичної активності визначає мислення, яке являє собою процес опосередкування узагальненого пізнання людиною предметів і явищ дійсності. Зароджуючись у чуттєвому пізнанні і спираючись на нього, мислення виходить за його межі. Осмислюючи, людина пізнає те, що вона не могла безпосередньо сприйняти і уявити, наближається до розуміння сутності явищ, формує поняття про них і практично оволодіває ними" [4, 15 - 16].

Професійна підготовка курсантів вищих навчальних закладів МВС України має реальні можливості впливу на їх інтелектуальноестетичний розвиток. Це стає можливим завдяки таким суспільно-гуманітарним дисциплінам, як юридична деонтологія, історія культури України, філософія, етика та естетика, психологія, ділова українська мова, іноземна мова, логіка та ін. В межах цих навчальних дисциплін відкривається можливість впливу на естетичну свідомість майбутніх правоохоронців, їх естетичний світогляд, систему понять про естетичне та його вияви у процесі професійної діяльності.

Вплив професійної підготовки на розвиток креативно-естетичних якостей майбутніх правоохорониів. Зазначимо, що сучасна вища школа покликана формувати творчу особистість, спроможну виявляти інноваційне мислення, здатність визначати своє ставлення до професійної діяльності на новаторській основі. Такої думки дотримуються вчені (Л. Печко, О. Павлова, О. Пташук, І. Радомська, Н. Рашидова, С. Решетник, В. Рибалка, А. Романова, В. Томашевський, Т. Черкасова, Б. Чупринський та ін.), які зазначають, що у процесі професійної підготовки відкриваються можливості розвитку таких креативо-естетичних якостей особистості, як творча уява, інноваційне мислення, уміння творчо інтерпретувати естетичні прояви навколишньої дійсності, передбачати характер використання естетичних ідей на практиці, приймати рішення щодо естетичної самореалізації в умовах професійної діяльності.

На необхідність посилення уваги вищої школи до розвитку креативного ставлення майбутніх фахівців до професійної діяльності вказує В. Кремень. На його думку, "необхідність трансформації, зміни способу мислення зумовлена вимогами інформаційної епохи, котра характеризується як “суспільство знань”. Проте наше мислення поки що залишається скоріше “лінійним”, вузькопрофесійним, ніж глобально орієнтованим, скоріше войовничим, ніж толерантним і готовим до компромісів, скоріше пасивно відображувальним, ніж продуктивно активним. Тому трансформація мислення в напрямі “нелінійності”, усвідомлення духовних цінностей сучасності - конструктивізму, коеволюції, інтерактивності, партнерства зі світом, складними структурами в ньому ставить умову його подальшого поступу” $[5,12]$.

Безперечно, професійна підготовка майбутніх офіцерів національної поліції України має бути спрямована на розвиток креативно-естетичних якостей. Майбутні фахівці правоохоронної діяльності в умовах професійного навчання покликані отримати досвід, який би забезпечив розвиток їх мислення на основі системного сприйняття предметів і явищ, у взаємозв'язку проявів внутрішнього і зовнішнього, форми і змісту, суспільного та особистісного, колективного та індивідуального, духовного та прагматичного, творчого та репродуктивного. Креативно-естетичні якості майбутніх правоохоронців не з'являються спонтанно. Їх розвиток покликані забезпечити вищі навчальні заклади МВС України, стимулюючи творче натхнення курсантів, залучаючи їх до творчого пошуку, формуючи естетичне ставлення до обраної професії офіцера національної поліції України.

Теоретичне дослідження проблеми дозволяє зазначити, що професійна підготовка $є$ важливим чинником розвитку емоційно-естетичних, інтелектуально-естетичних та креативноестетичних якостей майбутніх правоохоронців. Успішному вирішенню проблеми формування естетичної культури майбутніх офіцерів національної поліції України покликані сприяти освітньо-педагогічні можливості вищих навчальних закладів МВС України. До них віднесені: актуалізація проблеми формування естетичної культури у курсантів та визначення методологічних підходів до їївирішення, реалізація найважливіших принципів формування естетичної культури, збагачення її багатоаспектного змісту, використання ефективних освітньовиховних технологій та розвиток механізму самоорганізації естетичної культури (рис. 2).

Актуалізачія проблеми формування естетичної культури майбутніх офічерів національної поліиії. Важливо зазначити, що реформування правоохоронних органів та створення Національної поліції України зумовили якісні зміни в системі професійної підготовки майбутніх поліцейських. Затверджені МВС 
Освітньо-педагогічні можливості вищих навчальних закладів МВС України у формуванні естетичної культури майбутніх офіцерів національної поліції

\begin{tabular}{|c|c|c|c|c|c|}
\hline $\begin{array}{l}\text { Актуалізація } \\
\text { проблеми } \\
\text { формування } \\
\text { естетичної } \\
\text { культури } \\
\text { майбутніх } \\
\text { офіцерів поліції }\end{array}$ & $\begin{array}{l}\text { Визначення } \\
\text { методологічних } \\
\text { підходів до } \\
\text { формування } \\
\text { естетичної } \\
\text { культури } \\
\text { майбутніх } \\
\text { офіцерів поліції }\end{array}$ & $\begin{array}{l}\text { Реалізація } \\
\text { принципів } \\
\text { формування } \\
\text { естетичної } \\
\text { культури } \\
\text { майбутніх } \\
\text { офіцерів поліції }\end{array}$ & $\begin{array}{l}\text { Збагачення } \\
\text { багатоаспектного } \\
\text { змісту естетичної } \\
\text { культури } \\
\text { майбутніх } \\
\text { офіцерів поліції }\end{array}$ & $\begin{array}{l}\text { Використання } \\
\text { ефективних } \\
\text { технологій } \\
\text { формування } \\
\text { естетичної } \\
\text { культури } \\
\text { майбутніх } \\
\text { офіцерів поліції }\end{array}$ & $\begin{array}{l}\text { Розвиток } \\
\text { механізму } \\
\text { самоорганізації } \\
\text { естетичної } \\
\text { культури } \\
\text { майбутніх } \\
\text { офіцерів поліції }\end{array}$ \\
\hline
\end{tabular}

Рис. 2. Відображення освітньо-педагогічних можливостей вищих навчальних закладів МВС України у формуванні естетичної культури майбутніх офіцерів національної поліції

України Правила етичної поведінки поліцейських висувають перед вищими навчальними закладами вимогу щодо актуалізації проблеми формування духовно-моральних та естетичних якостей майбутніх офіцерів поліції. Вирішенню цього питання покликані сприяти навчальна, наукова, позааудиторна та культуротворча діяльність викладачів та курсантів; система підвищення професорсько-педагогічної культури та майстерності викладачів та співробітників вищих навчальних закладів; освітньо-виховні заходи, присвячені актуальним питанням формування естетичної свідомості, світогляду, досвіду, активності майбутніх фахівців правоохоронної діяльності.

Визначення методологічних підходів до формування естетичної культури майбутніх офіцерів поліції. Освітньо-педагогічні можливості вищих навчальних закладів МВС України у формуванні естетичної культури майбутніх офіцерів поліції полягають не лише у забезпеченні актуалізації означеної проблеми, але й у прийнятті рішень щодо методологічних підходів до формування естетичної культури майбутніх фахівців правоохоронної діяльності. В залежності від прийнятих на методологічному рівні рішень відбувається моделювання навчально-виховного процесу, визначаються пріоритетні напрямки та завдання, які прагнуть вирішувати навчальні заклади, створюються педагогічні умови, розраховані на конкретні освітньо-виховні дії. Саме тому особливої гостроти й актуальності набуває питання щодо методологічного спрямування освітньо-виховного впливу та ефективного упровадження упроцесі формування естетичної культури майбутніх офіцерів національної поліції таких підходів, як культурологічний, особистісно-орієнтований, діяльнісний, системний, синергетичний та компетентнісний.
Реалізація принципів формування естетичної культури майбутніх офіцерів національної поліuіï. Важливо зазначити, що методологічні підходи до формування естетичної культури майбутніх фахівців визначають стратегічні параметри означеного процесу, його мету, завдання, напрями, пріоритети. Утім, ефективність освітньо-педагогічних дій знаходиться в залежності від принципів, які сповідують у своїй діяльності викладачі та співробітники вищих навчальних закладів. Вони не передбачають нормативну регламентацію педагогічних дій і в значній мірі залежать від особистості викладача вищої школи. Саме тому важливого значення набуває питання щодо принципів формування естетичної культури майбутніх офіцерів національної поліції, які спроможні оптимізувати означений процес, надати йому систематичного, послідовного та ефективного характеру.

Збагачення змісту естетичної культури майбутніх офіцерів національної поліції. Теоретичне осмислення освітньо-педагогічних можливостей вищих навчальних закладів у формуванні естетичної культури майбутніх офіцерів національної поліції України дозволяє акцентувати увагу на інформаційній складовій означеного процесу. Дійсно, вища школа в системі МВС України має значний інформаційний потенціал, що дозволяє використовувати в навчально-виховному процесі різні види інформації. Йдеться, зокрема, про такі різновиди інформації, як соціальна, наукова, художня, естетична та ін. Для формування естетичної культури курсантів важливим $€$ виокремлення освітньо-виховних можливостей різних видів та джерел інформації, створення умов для освоєння майбутніми офіцерами національної поліції не лише спеціальних та професійно-орієнтованих 


\section{РОЛЬ ПРОФЕСІЙНОЇ ПІДГОТОВКИ У ФОРМУВАННІ ЕСТЕТИЧНОЇ КУЛЬТУРИ МАЙБУТНІХ ОФІЦЕРІВ НАЦІОНАЛЬНОӤ ПОЛІЦІЇ УКРАЇНИ}

знань, але й інформаційних матеріалів, спроможних збагатити їх знання, поняття, уявлення про естетичне як складову їх духовної та професійної культури.

Використання ефективних технологій формування естетичної культури майбутніх офічерів національної поліиії. Ця освітньопедагогічна можливість вищих навчальних закладів МВС України має важливе значення. Адже у розпорядженні викладачів та співробітників вищої школи знаходяться не лише інформаційні джерела та матеріали, але й організаційно-педагогічні дії та способи впливу на естетичну свідомість та активність курсантів. Це зумовлює необхідність широкого залучення до вказаного процесу відповідних технологій, методів та засобів естетико-педагогічного впливу. Важливо, що в арсеналі технологічних та методичних рішень знаходиться широкий набір форм, методів, способів залучення курсантів до естетичних цінностей. Саме тому виявляється доцільним упровадження на практиці сугестивних, інформаційних, діяльнісних та креативних технологій формування естетичної культури майбутніх офіцерів національної поліції, забезпечення готовності викладачів та співробітників вищої школи МВС України до ефективного вирішення означеної проблеми.

Розвиток механізму самоорганізаиії естетичної культури майбутніх офіцерів національної поліиії. Звернення до цієї освітньопедагогічної можливості вищих навчальних закладів МВС України у формуванні естетичної культури майбутніх офіцерів національної поліції має теоретичне обгрунтування. Відомо, що естетична культура являє собою особистісне духовно-функціональне утворення, яке спирається у своєму розвитку на зовнішні та внутрішні чинники впливу. Для майбутніх офіцерів національної поліції є важливим розвиток механізму не лише зовнішньої, але й внутрішньої детермінації. На забезпеченні цього процесу мають зосереджувати свою увагу викладачі та співробітники вищої школи, створюючи відповідні умови для самоорганізації естетичної культури курсантів, підвищення їх самостійності й відповідальності у взаємодії 3 естетичними цінностями.

Висновки і перспективи професійних досліджень. Теоретичний аналіз означеної проблеми дозволив узагальнити результати наукових досліджень і на цій основі обгрунтувати роль професійної підготовки у формуванні естетичної культури майбутніх офіцерів національної поліції України, з'ясувати можливості вищих навчальних закладів МВС України у залученні курсантів до естетичних цінностей, спрямованих на підвищення якості та ефективності правоохоронної діяльності. Подальший науковий пошук передбачає обгрунтування критеріїв та показників сформованості естетичної культури майбутніх офіцерів поліції.

\section{ЛІТЕРАТУРА}

1. Кремень В.Г. Особистість в освітній системі // Теоретико-методологічні проблеми розвитку особистості в системі неперервної освіти: матеріали методологічного семінару АПН Украӥни 16 грудня 2004 року /ред. С.Д. Максименка. Київ. 2005. C. $3-17$.

2. Шевченко Г.П. Естетичне одухотворення студентської молоді //Педагогічна і психологічна науки в Україні: збірник наукових праџь до 15-річчя АПН Украӥни в 5-ти т. Київ: Педагогічна думка, 2007. T. 4. Педагогіка і психологія вищої школи. C. $215-225$.

3. Наказ МВС України № 1179 від 09. 11. 2016 р. “Про затвердження Правил етичної поведінки поліцейських”: офіи. видання: Офічійний вісник України. Київ, 2017. Вип. 2.

4. Развитие эстетической активности школьников: пособие для учителя / В.Г. Бутенко и др. Киев, 1992. $174 \mathrm{c}$.

5. Кремень В.Г. Освіта у вимірах методологіï синергетики // Педагогічна і психологічна науки в Украӥні: зб. наук. праць в 5 m. T.1. Загальна педагогіка та філософія освіти. Київ: Педагогічна думка, 2012. С. $11-23$.

\section{REFERENCES}

1. Kremen, V.G. (2005). Osobystist v osvitnii systemi [Personality in the educational system]. Kyiv: Pedahohika i psykholohiia vyshchoi shkoly, pp. 3-17. [in Ukrainian].

2. Shevchenko, H.P. (2007). Estetychne odukhotvorennia studentskoi molodi [Aesthetic inspiration of student youth]. Kyiv: Pedahohichna dumka, pp. 215-225. [in Ukrainian].

3. Order of the Ministry of Internal Affairs of Ukraine No. 1179 dated 09. 11. 2016 "On Approval of the Rules of Ethical Conduct of Police": official publication. Kyiv: Official Bulletin of Ukraine, 2017. Edition 2. [in Ukrainian].

4. Butenko, V.G. and others (1992). Razvytye estetycheskoi aktyvnosty shkolnykov: posobye dlia uchytelia [Development of aesthetic activity of schoolchildren: a manual for a teacher]. Kyiv, 174 p. [in Ukrainian].

5. Kremen, V.G. (2012). Osvita u vymirakh metodolohii synerhetyky [Education in measurements of the synergy methodology]. Kyiv: Pedahohichna dumka, pp. 11-23. [in Ukrainian].

Стаття надійшла до редакції 12.02.2018 